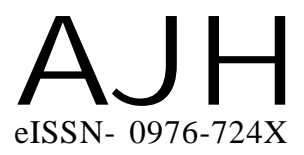

Received : 02.08.2014

Revised : 23.10.2014

Accepted : 05.11.2014
Members of the Research Forum

Associated Authors:

${ }^{1}$ Department of Vegetable Science,

College of Agriculture, Orissa

University of Agriculture and

Technology, BHUBANESWAR

(ODISHA) INDIA

${ }^{2}$ Department of Fruit Science and Horticulture Technology, College of Agriculture, Orissa University of

Agriculture and Technology,

BHUBANESWAR (ODISHA) INDIA

Author for correspondence : N. MISHRA

Department of Vegetable Science, College of Agriculture, Orissa

University of Agriculture and

Technology, BHUBANESWAR (ODISHA) INDIA

Email : nityamanjari.mishra@gmail. com
THE ASIAN JOURNAL OF HORTICULTURE

Volume 9 | Issue 2 |Dec., 2014 |382-385

Visit us -www.researchjournal.co.in

\title{
Effect of integrated nutrient management on yield, quality and economics of knolkhol (Brassica oleracea L. cv. GONGYLODES)
}

\section{P.P. MISHRA ${ }^{1}$, A.K. DAS ${ }^{2}$ AND N. MISHRA}

ABSTRACT : An experiment was carried out in the College of Agriculture, Orissa University of Agriculture and Technology, Bhubaneswar during Rabi 2012-13. The experiment comprised of 11 treatments replicated three times in a Randomized Block Design. Of the eleven treatments seven comprised of 100 per cent NPK with or without organic nutrient supplements, two treatments with 50 per cent NPK +organic nutrient supplements, one treatment with no nutrients $\left(\mathrm{T}_{1}-\right.$ control), and one treatment with only biofertilizers. The $\mathrm{T}_{7}$ which comprised of 100 per cent NPK (@ 150-38-63 kg NPK $\mathrm{ha}^{-1}$ ) application along with vermicompost (@2.5 $\mathrm{t} \mathrm{ha}^{-1}$ ), biofertilizer @ $2 \mathrm{~kg} \mathrm{ha}^{-1}$ each of Azotobacter, Azospirillum and PSB) recorded significantly higher values for total dry weight per plant (77.8 g), yield $\left(420.0 \mathrm{q} \mathrm{ha}^{-1}\right)$, chlorophyll content $(56.96 \%)$ TSS $\left(3.1^{0} \mathrm{Brix}\right)$, ascorbic acid content $(55.2 \mathrm{mg} /$ $100 \mathrm{~g}$ ) and protein content $(44.2 \mathrm{~g} / 100 \mathrm{~g})$ followed by $\mathrm{T}_{6}$. The treatment $\mathrm{T}_{6}$ had same nutrients as $\mathrm{T}_{7}$ except, FYM instead of vermicompost. But the $\mathrm{T}_{6}$ proved to be most economical treatment with a benefit:cost ratio of 2.7 .

KEY WORDS : Economics INM, Knolkhol, Quality, Yield

HOW TO CITE THIS ARTICLE : Mishra, P.P., Das, A.K. and Mishra, N. (2014). Effect of integrated nutrient management on yield, quality and economics of knolkhol (Brassica oleracea L. cv. GONGYLODES). Asian J. Hort., 9(2) : 382-385. 